Article

\title{
Identification of Woodland Vernal Pools with Seasonal Change PALSAR Data for Habitat Conservation
}

\author{
Laura L. Bourgeau-Chavez ${ }^{1, *}$, Yu Man Lee ${ }^{2}$, Michael Battaglia ${ }^{1}$, Sarah L. Endres ${ }^{1}$, \\ Zachary M. Laubach ${ }^{1}$ and Kirk Scarbrough ${ }^{1}$ \\ 1 Michigan Tech Research Institute, Michigan Technological University, 3600 Green Ct. Suite 100, Ann Arbor, \\ MI 48105, USA; mjbattag@mtu.edu (M.B.); slendres@mtu.edu (S.L.E.); zchlaubach@gmail.com (Z.M.L.); \\ kascarbr@mtu.edu (K.S.) \\ 2 Michigan Natural Features Inventory, Michigan State University Extension, P.O. Box 13036, Lansing, \\ MI 48901, USA; leeyum@msu.edu \\ * Correspondence: lchavez@mtu.edu; Tel.: +1-734-913-6873
}

Academic Editors: Javier Bustamante, Alfredo R. Huete, Patricia Kandus, Ricardo Díaz-Delgado, Josef Kellndorfer and Prasad S. Thenkabail

Received: 2 March 2016; Accepted: 2 June 2016; Published: 10 June 2016

\begin{abstract}
Woodland vernal pools are important, small, cryptic, ephemeral wetland ecosystems that are vulnerable to a changing climate and anthropogenic influences. To conserve woodland vernal pools for the state of Michigan USA, vernal pool detection and mapping methods were sought that would be efficient, cost-effective, repeatable and accurate. Satellite-based L-band radar data from the high $(10 \mathrm{~m})$ resolution Japanese ALOS PALSAR sensor were evaluated for suitability in vernal pool detection beneath forest canopies. In a two phase study, potential vernal pool (PVP) detection was first assessed with unsupervised PALSAR (LHH) two season change detection (spring when flooded-summer when dry) and validated with 268,1 ha field-sampled test cells. This resulted in low false negatives (14\%-22\%), overall map accuracy of $48 \%$ to $62 \%$ and high commission error (66\%). These results make this blind two-season PALSAR approach for cryptic PVP detection of use for locating areas of high vernal pool likelihood. In a second phase of the research, PALSAR was integrated with $10 \mathrm{~m}$ USGS DEM derivatives in a machine learning classifier, which greatly improved overall PVP map accuracies (91\% to 93\%). This supervised approach with PALSAR was found to produce better mapping results than using LiDAR intensity or C-band SAR data in a fusion with the USGS DEM-derivatives.
\end{abstract}

Keywords: synthetic aperture radar; DEM; vernal pools; LiDAR

\section{Introduction}

Due to increased awareness of the ecological significance of vernal pools, there has been growing interest in identifying, mapping, monitoring, and protecting these valuable forested wetlands. Vernal pools are small (typically less than $1 \mathrm{ha}$ ), shallow, isolated, temporary wetlands that are important for maintaining healthy forest ecosystems. In addition, known as temporary or ephemeral ponds, vernal pools occur in various forms throughout the world [1]. In most years, vernal pools are filled with water in the spring, and dry or significantly draw down in summer, exposing all or most (i.e., $>50 \%$ ) of the pool bottom. As confined-basin depressions, they lack continuously flowing inlets or outlets, and they have no continuous surface-water connection with permanently flooded water bodies. Woodland vernal pools generally contain water for a minimum of two months in most years and the regular drying prevents fish from establishing populations in these wetlands. Reduced predation pressure from fish and minimum hydroperiods of two months allow the eggs and larvae of many of the 
amphibians and invertebrates that breed in vernal pools to successfully complete their development, metamorphose into adults, and leave the pools. Vernal pools, therefore, provide critical breeding habitats for amphibians and invertebrates, including obligate (a species that requires or is restricted to a specific habitat or environmental conditions) species that rely on vernal pools to complete their life cycle and a number of rare and declining plant and animal species [2-11]. Additionally, there are important ecosystem services that vernal pools provide, such as nutrient cycling, water storage, groundwater aquifer recharge, flood control, and improved water quality [5,11-15]. Due to their small size and short hydroperiods, vernal pools are vulnerable to climate change and land use development. Researchers and resource managers agree that these important ecosystems need to be protected, but conservation of these small isolated ecosystems requires knowledge of their location and distribution, which is largely unknown. Conservation also requires information about their biology and ecology, which needs to be sampled in the field.

Due to their small size, temporary and isolated nature, and association with forested ecosystems, vernal pools can be challenging to locate with conventional surveying and mapping techniques. Currently, the most common approach to inventorying and mapping vernal pools is through aerial photograph interpretation [16-21]. A number of state governments within the United States of America have implemented efforts to identify and map vernal pools within their jurisdictions (e.g., Massachusetts, Maine, New Hampshire, New Jersey, Rhode Island, and Vermont) $[5,11,19,20]$. These efforts have consisted of remotely identifying and mapping water features within forests that are labeled potential vernal pools (PVPs) and then conducting necessary field surveys to confirm that the identified water features are actual vernal pools. After confirmation, the PVPs are upgraded to a status of confirmed vernal pools (CVPs). This naming convention is followed in the research presented in this article.

While aerial photo interpretation and field surveys can be fairly effective in identifying and mapping vernal pools, these approaches are time- and labor-intensive and expensive to implement across large regions [5]. In addition, there are limitations to optical-based imagery in detecting pools beneath tree canopies. Image interpreters typically rely on spring photos to obtain the best detection of PVPs because in leaf-off conditions the amount of foliage blocking the view of sub-canopy features is minimized. Vegetation layers within the pools are variable and may consist of trees, shrubs, submergent and floating aquatics. However, the utility of this approach is limited to deciduous forests and generally fails in the case of dense evergreen forest cover (e.g., conifers). The accuracy of aerial photograph interpretation varies depending on landscape characteristics, surrounding forest cover, pool type and size, timing of the aerial photography, photograph scale, and interpreter experience [5,17-20,22]. These limitations have led researchers and resource managers to investigate other image sources for detecting and mapping PVPs (e.g., radar and/or LiDAR data) [23-25].

The low frequency radar sensors (synthetic aperture radar-SAR) are able to penetrate forest canopy cover to detect the presence of standing water at the ground surface. In addition, the all-weather capability of SAR sensors allows for timely collection of data to detect flooded conditions in the spring, irrespective of cloud cover. For example, L-band $(\sim 24 \mathrm{~cm})$ wavelengths produce characteristic enhanced (bright) radar signatures from forests in a flooded condition because much of the incoming energy is reflected back to the antenna due to double-bounce scattering (dihedral effects, Figure 1). In a non-flooded forest, more of the incoming energy is absorbed by the ground and the backscatter signatures are moderate, with gray image tones. While shorter wavelength C-band $(\sim 5.6 \mathrm{~cm})$ reflects primarily off the canopy (Figure 1), when there are gaps in the canopy or leaf-off conditions, penetration of C-band energy to the ground does occur (not shown in Figure 1). L-band is theoretically the better SAR wavelength for PVP detection in leaf-off and leaf-on conditions, while C-band may only provide limited utility under leaf-off or low density forest conditions. 


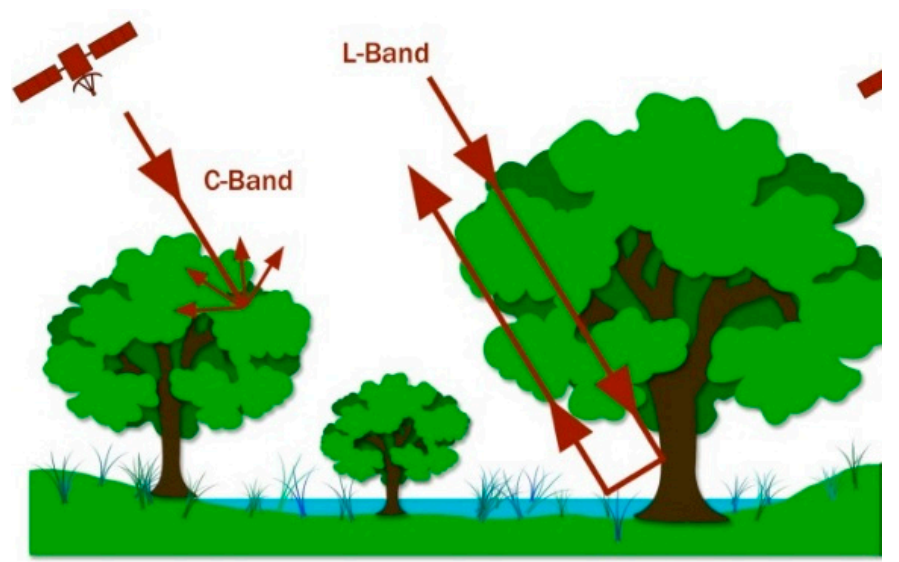

Flooded Forest

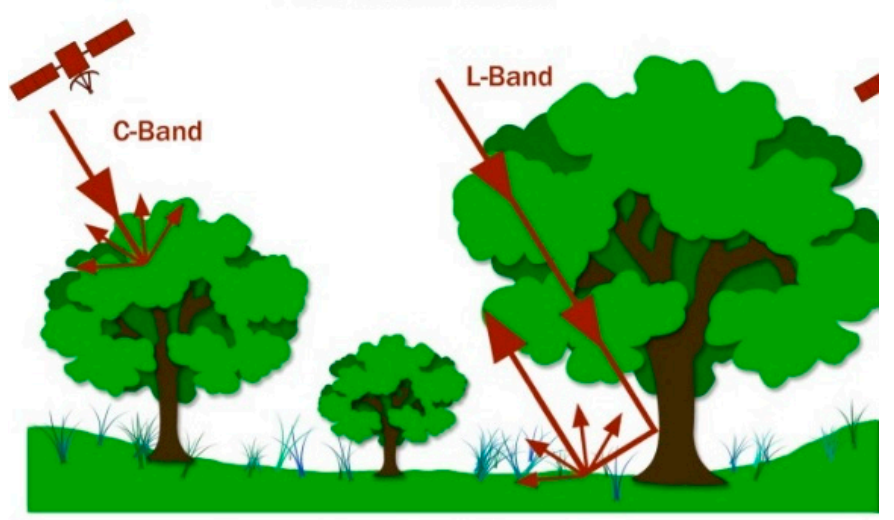

Non-Flooded Forest

Figure 1. Schematic showing the theoretical scattering of L-band ( $\sim 24 \mathrm{~cm}$ wavelength) and C-band ( $5.6 \mathrm{~cm}$ wavelength) SAR from flooded versus non-flooded forests. In leaf off condition or with significant gaps in the canopy C-band will penetrate to the forest floor similar to L-band.

LiDAR (Light Detection and Ranging) sensors are typically used to create high resolution Digital Elevation Models (DEMs) that are useful for delineating low lying areas indicative of PVPs e.g., [24]. The intensity of the returns has also been used to map extent of inundation of forested wetlands in leaf-off conditions [26]. The mapping is possible because of the high absorption of incident near-infrared by water, often resulting in very low returns from inundated forests when leaves are off. While scan angle (glint), surface roughness and other variables influence whether or not the energy is absorbed, these limitations can be accounted for and using LiDAR intensity for mapping forest inundation is an active area of research. However, LiDAR data availability for the region of interest (the state of Michigan) is limited to merely a few counties. It was therefore not a main focus of study.

The goal of our research was to develop a remote sensing method for mapping vernal pools across the state of Michigan that would be efficient, cost-effective, repeatable and accurate. We evaluated satellite-based L-band radar data from the high $(10 \mathrm{~m})$ resolution Japanese ALOS PALSAR FBS (fine beam single) imagery (collected between 2006 and 2011) to determine if it could be used to effectively detect vernal pools. Using the definition of a vernal pool, as described above (that they are forest covered and flooded in the spring and dry in the summer), we hypothesized that two seasons of radar imagery (spring and summer) could be used to capture these hydrological differences for distinction of vernal pools from non-wetlands, as well as from permanently-flooded wetlands which should have a bright L-band signature in both spring and summer. We also evaluated LiDAR intensity data and Radarsat-2 C-band high resolution data for suitability in detection of vernal pools. 


\section{Materials and Methods}

\subsection{Criteria for Selection of Study Areas}

Several areas within Michigan including the western Upper Peninsula (WUP), southeastern Lower Peninsula (SLP), and northeastern Lower Peninsula (NLP) were targeted for this study (Figure 2). These areas include distinct ecoregions [27] suspected to support an abundance of vernal pools because of the presence of bedrock, fine-textured soils, or high water tables near the surface that would impede surface water infiltration. To help identify potential study areas, a GIS-based hotspot analysis was performed on isolated forested wetlands based on palustrine wetlands in the National Wetland Inventory (NWI) and concentrations of hydrologically isolated wetlands in forested settings were thereby identified [23]. This analysis helped limit (stratify) our mapping to areas in the state with a high potential to exhibit vernal pools. Several areas in Michigan's Upper and Lower Peninsula were chosen to test the effectiveness of remote sensing methods for mapping vernal pools to determine if there was any regional variability in the approaches. All study areas were located on public lands in relatively undeveloped areas (i.e., federal and state forest lands and state recreation areas). Study areas were also limited to parts of the state that had archival $10 \mathrm{~m}$ FBS PALSAR data (Figure 3) and aerial photographs available from the seasons of interest (i.e., available radar data for spring and summer/flooded and not flooded conditions as well as high resolution, color-infrared leaf-off aerial photographs).

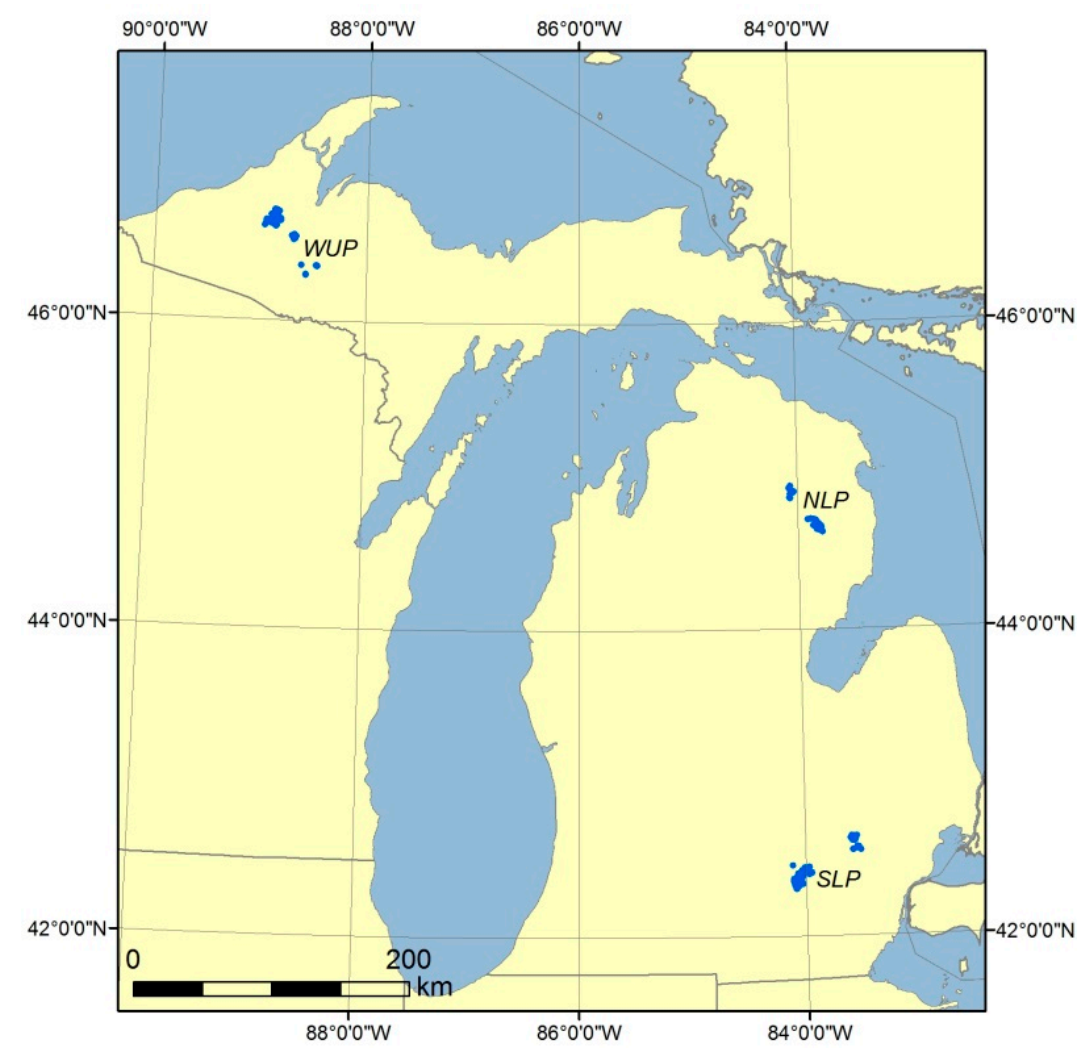

Figure 2. Map of Michigan showing in blue the potential vernal pool study areas that were the focus of research including the western Upper Peninsula (WUP), northeastern Lower Peninsula (NLP), and southeastern Lower Peninsula (SLP). 


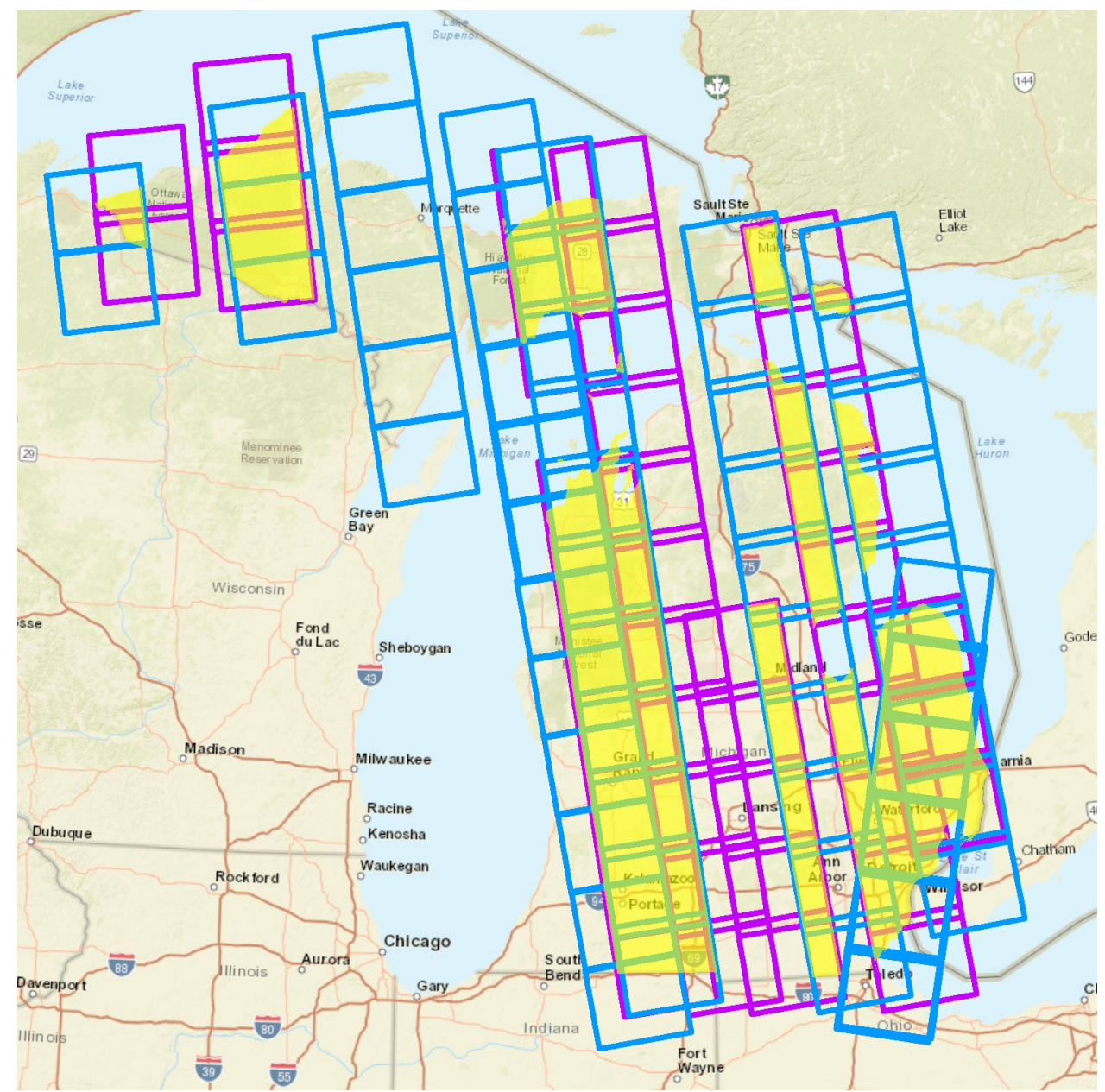

Figure 3. Map shows optimal PALSAR footprints for $10 \mathrm{~m}$ Fine Beam Single data from Spring as "blue" for summer as "purple" and the yellow shows the overlap.

The climatic conditions of the study areas are continental but vary in growing season length, temperature and precipitation. The SLP study area has a growing season of 140 to 150 days, annual average snowfall of 100-127 cm, total precipitation of 76 to $81 \mathrm{~cm}$ and a minimum temperature of $-31^{\circ} \mathrm{C}$ [27]. The NLP has a shorter growing season (70-130 days) and colder minimum temperatures $\left(-37^{\circ} \mathrm{C}\right.$ to $\left.-45^{\circ} \mathrm{C}\right)$ with more snow $(127-355 \mathrm{~cm})$ but similar total precipitation $(71$ to $81 \mathrm{~cm})$. The WUP is the most extreme of the study areas with heavy snow $(101$ to $355 \mathrm{~cm}$ ) and extremely cold winters. Growing season is merely 87 days with an average minimum temperature of $-45^{\circ} \mathrm{C}$ [27].

The vegetation also varies among the study areas, with the dominant natural community around sampled vernal pools (i.e., within $30 \mathrm{~m}$ ) of the SLP characterized as dry-mesic southern forest [28]. The vegetation canopy layer of the dry-mesic southern forest is generally dominated by white oak (Quercus alba) and/or black oak (Q. velutina). For the NLP, the dominant types were mesic northern forest and dry-mesic northern forest [28]. Mesic northern forests are characterized by the dominance of northern hardwoods, particularly sugar maple (Acer saccharum) and American beech (Fagus grandifolia). Conifers such as hemlock (Tsuga canadensis) and white pine (Pinus strobus) are frequently important canopy associates. Dry-mesic northern forests are pine or pine-hardwood forests dominated by white pine, red pine (Pinus resinosa) and hemlock. Hardwood associates include white oak, black oak, red oak (Q. rubra), red maple (A. rubrum), paper birch (Betula papyrifera), aspen (Populus tremuloides and P. grandidentata), and balsam poplar (P. balsamifera). For the WUP, the sampled pools were surrounded by mesic northern forest, with coniferous species, such as hemlock, white pine, and 
northern white-cedar (Thuja occidentalis) dominant in the canopy and hardwood associates, however beech was absent.

\subsection{Field Sampling Methods}

Sampling Design and Surveying Methods

Field sampling was conducted in all three study areas (Figure 2) in 2012 and 2013 to identify presence of vernal pools on the ground, verify and map locations. Field sampling was conducted during two different time periods; early season sampling from 4 May to 14 June 2012 to identify PVPs when they are typically filled with water and late season sampling from 14 August to 2 November 2012 to revisit identified PVPs to confirm draw down and to sample additional PVPs. A stratified random sampling design was used for the field surveys. A sampling grid of 1-ha (2.5 ac) test cells was overlaid on each study area (Figure 2) and the cells were randomly numbered. The first 150 of these randomly ordered cells were selected for field sampling in the early season of 2012. Since only a small number of these 150 test cells contained PVPs from aerial photograph interpretation, we selected an additional 40 test cells from each area that contained at least one aerial photograph interpreted PVP and randomly ordered these for sampling in the late season (2012). These were added to better estimate commission error.

The entire area within sampled test cells was surveyed. Two observers would systematically walk a series of transects or passes through each 1-ha test cell selected for sampling to identify and locate vernal pools within the test cell. Observers divided up the test cell into halves or thirds, and walked parallel to each other through the test cell from end to end, making one or two passes through depending on visibility (e.g., vegetation type and density, slope, etc.) to detect vernal pools within the test cell.

A total of 402 test cells were sampled across all three study areas; including 125 in the SLP, 168 in the NLP, and 109 in the WUP study area. Within the test cells, 38 PVPs were mapped in the NLP study area, 37 in the SLP study area, and 30 in the WUP. In 2013, PVPs that had been field-mapped in the test cell were surveyed to confirm their status (i.e., CVP), and additional new or previously unmapped PVPs were identified and located within the sample test cells as well. All vernal pools are not wet every spring and the timing of inundation may vary from year to year or between pools, thus repeating the surveys in subsequent years is useful and necessary.

To provide additional data to evaluate the suitability of using L-band and C-band SAR data to detect and map PVPs, additional field surveys were conducted in 2013 and 2014 in the SLP and WUP study areas. These surveys focused on visiting and verifying individual PVPs that had been identified as PVPs from ground surveys described above and/or aerial photograph interpretation. A total of 30 PVPs in the SLP study area and 35 PVPs in the WUP study areas were surveyed in 2013-2014. Field sampling in 2013 and 2014 followed the vernal pool survey and monitoring protocol developed for the Michigan Volunteer Vernal Pool Mapping and Monitoring Program [29]. The protocol consists of conducting three visits a year to view the different stages of the vernal pool (early spring, mid-spring, and late summer/early fall). Information on the physical and ecological characteristics of the pools was collected during these surveys. The pool size, cover type, substrate type, water level, vegetation/cover in pool, the surrounding habitat and any disturbances were all recorded each visit. Indicator species and other animal species were identified and counted. A diagram of the pool was drawn along with a GPS center point and GPS tagged photos were taken in the four cardinal directions.

\subsection{Remote Sensing Datasets}

ALOS PALSAR L-band HH polarization, Radarsat-2 C-band HH polarization and an airborne LiDAR dataset were evaluated for vernal pool detection. In addition, USGS $10 \mathrm{~m}$ resolution digital elevation models (DEM) were used as an ancillary dataset. The imagery available for evaluation varied by site (Table 1). 
Table 1. Summary of datasets evaluated for the detection of vernal pools including source imagery, year, resolution and sites covered. Two image dates were used per site (spring and summer).

\begin{tabular}{ccccc}
\hline Data Set & Date of Acquisition & Sites & Resolution & Incidence Angle \\
\hline \multirow{3}{*}{ PALSAR FBS L-HH } & 2 April 2006 and 12 July 2006 & WUP & & \\
& $\begin{array}{c}\text { 31 May 2006 and 14 August 2006 } \\
\text { 31 May 2006 and 2 August 2006 }\end{array}$ & $\begin{array}{c}\text { NLP } \\
\text { SLP }\end{array}$ & $10 \mathrm{~m}$ & $34.3^{\circ}$ and $41.5^{\circ}$ \\
\hline Radarsat-2 FQ & 31 May 2014 and 4 September 2014 & WUP & $5-8 \mathrm{~m}$ & $\begin{array}{c}19^{\circ} \text { (WUP) } \\
\text { C-HH }\end{array}$ \\
24 April 2014 and 29 July 2014 & SLP & (SLP) \\
LiDAR & Spring 2009 & SLP & 1 m & Nadir \\
\hline
\end{tabular}

\subsubsection{LiDAR}

The LiDAR data for Washtenaw County were collected using a LH Systems ALS50 at $1064 \mathrm{~nm}$ wavelength with scan frequency of $65.3 \mathrm{Hertz}$ and $1.5 / \mathrm{m}^{2}$ point density in the spring of 2009 for the Southeastern Michigan Council of Governments (SEMCOG). The LiDAR data were processed to a $1 \mathrm{~m}$ resolution DEM and a $1 \mathrm{~m}$ resolution intensity image using Quick Terrain Modeler [30] software. Only the LiDAR intensity data are presented in this study. The LiDAR intensity analysis was exploratory to determine the utility for PVP detection. Since LiDAR data were unavailable for the NLP and WUP study areas and limited in the SLP, but the $10 \mathrm{~m}$ USGS DEMs were available for the entire state through the USGS, the latter were chosen to produce DEM derivatives for integration with PALSAR for this research study. LiDAR DEM data have been evaluated for PVP detection by others [24].

\subsubsection{USGS $10 \mathrm{~m}$ DEM}

The USGS 10 m DEM products used are from the 3D Elevation Program (3DEP) [29,31]. The $10 \mathrm{~m}$ DEM products with $1.55 \mathrm{~m}$ vertical accuracy from the USGS were used to create two additional products, a Topographic Position Index (TPI) and an isolated depressions map:

\section{Development of Isolated Depressions Maps from USGS DEM}

A method to create a map of isolated depressions was developed using ArcGIS. Pixels in the $10 \mathrm{~m}$ USGS DEM with values lower than each of their surrounding eight neighbors are filled to the level of their lowest neighbor using the ArcGIS Fill tool from the Spatial Analyst Toolbox. This process is iterated until all sinks are filled. This method is typically used to eliminate imperfections in elevation models for hydrologic analyses, but was exploited for this project by subtracting the depression-less DEM from the original DEM. The resulting dataset shows only the locations of isolated depressions. These depressions are, in theory, independent of local surface-water hydrology, which is one of the main criteria used for vernal pool verification. These data were then used as an input layer to the Random Forests Classifier.

\section{Development of the TPI from USGS DEM}

Topographic Position Index (TPI) is a measure of a point's elevation relative to the area immediately surrounding it [32]. To calculate TPI, each cell in the $10 \mathrm{~m}$ USGS DEM was compared to the average value of cells in its surrounding neighborhood. In the resulting dataset, negative values indicate the cell is relatively lower in elevation than the area around it, while positive values indicate the cell is relatively higher in elevation. TPI is highly dependent on input parameters such as the shape and size of the neighborhood. For this project, a circular neighborhood with a 10 cell (100 m) radius was used.

\subsubsection{SAR Data}

The high resolution Fine Beam single (FBS) product of ALOS PALSAR (Phased Array type L-band Synthetic Aperture Radar on board the Advanced Land Observing Satellite) was the focus of study with its L-band $(\sim 24 \mathrm{~cm})$ wavelength at $10 \mathrm{~m}$ resolution and HH-polarization. Archival PALSAR FBS images were obtained in 2012 through the Alaska Satellite Facility (ASF) and processed and 
radiometrically terrain corrected in ASF's MapReady software, which uses the Ulander approach to mitigate the effect of local terrain variability $[33,34]$. PALSAR has a radiometric accuracy $\pm 0.64 \mathrm{~dB}$ and a noise equivalent of $-31.1 \mathrm{~dB}$ for $\mathrm{HH}[35,36]$.

Radarsat-2's C-band ( $\sim 5.6 \mathrm{~cm})$ wavelength data in fine quad (FQ) polarization were tasked for spring and summer collection for two of the study areas in 2014 to test the applicability of C-band on woodland vernal pool detection. Radarsat- 2 data were processed and radiometrically terrain corrected in PCI Geomatica. Radarsat-2 has a reported radiometric accuracy within $0.43 \mathrm{~dB}$ [37].

All SAR data were georeferenced to UTM using bilinear interpolation. The data were further geocorrected to each other in Erdas Imagine to within 1 pixel using Landsat TM Images as reference. A $3 \times 3$ median filter was applied to the SAR imagery to reduce speckle. Speckle is the coherent addition of backscatter from multiple scatterers in the same resolution cell, and is inherent to all SAR imagery. The result is random constructive and destructive interference, manifesting itself in bright and dark neighboring pixels that have the appearance of "salt and pepper". Because of speckle, a single pixel in SAR imagery cannot be used to measure features on the ground without further processing, therefore, a filter was applied to the SAR data.

\section{Development of SAR Seasonal Change Images}

Using the hydroperiod of a vernal pool, as defined in this article, wet in spring and dry in summer, seasonal change images were created between spring and summer PALSAR HH-polarization data of similar incidence angle for the various sites. Optimal spring and summer SAR data were selected which did not have more than a trace of rain within the previous $24 \mathrm{~h}$ of the collection date (local weather stations were used to check rainfall). Scenes with rainfall were avoided since water on plant leaves and the soil could have a significant effect on the backscatter signal. Forested areas exhibiting backscatter greater than $-5.23 \mathrm{~dB}$ in the spring scene were considered flooded. This determination was made by examining pixel values at both known flooded and dry forest locations. The speckle filtered spring image was therefore thresholded to only show pixels with backscatter of $-5.23 \mathrm{~dB}$ (linear scale $0.3)$ or greater. The reclassified spring image was then subtracted from the summer image. Negative values in the resulting product were areas with decreased backscatter, indicative of drying, and were considered to be areas that could be PVP locations (Figure 4).

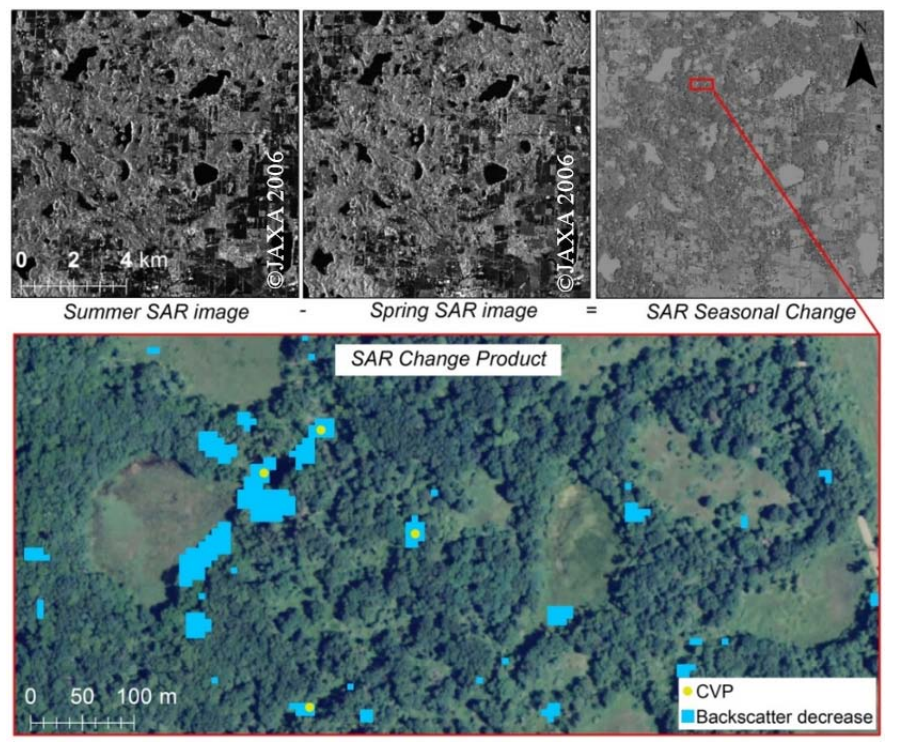

Figure 4. Example of the Summer and Spring PALSAR images and resulting Seasonal change Image. In the SAR seasonal change image areas of negative change are shown as cyan. A subsetted area is shown below with the cyan (negative change) values overlaid on an aerial image and confirmed vernal pool (CVP in yellow) field points overlaid. 


\subsection{Remote Sensing Approach}

The assessment of SAR for vernal pool mapping was implemented in two phases (Figure 5). In phase I, remote sensing methods developed without field training data (unsupervised approaches) were tested for detecting PVPs in the study areas selected (Figure 2). The SAR seasonal change images described above were the basis of the Phase I unsupervised PVP maps (Figure 5). Once the negative change values were extracted from the seasonal change images, the change maps were filtered with a forest/non-forest map based on the 2010 NOAA Coastal Change Analysis Program (C-CAP) landcover map ([38], Figure 5). This last step was conducted to limit the errors in non-forested areas, which may also cause a negative change from spring to summer (e.g., spring to summer changes in agricultural lands).This first phase was conducted in 2012 and allowed comparison of blind methods of PVP detection (PALSAR seasonal change) to the 2681 ha test cells concurrently sampled in 2012, to establish the viability of the PALSAR methods [23].
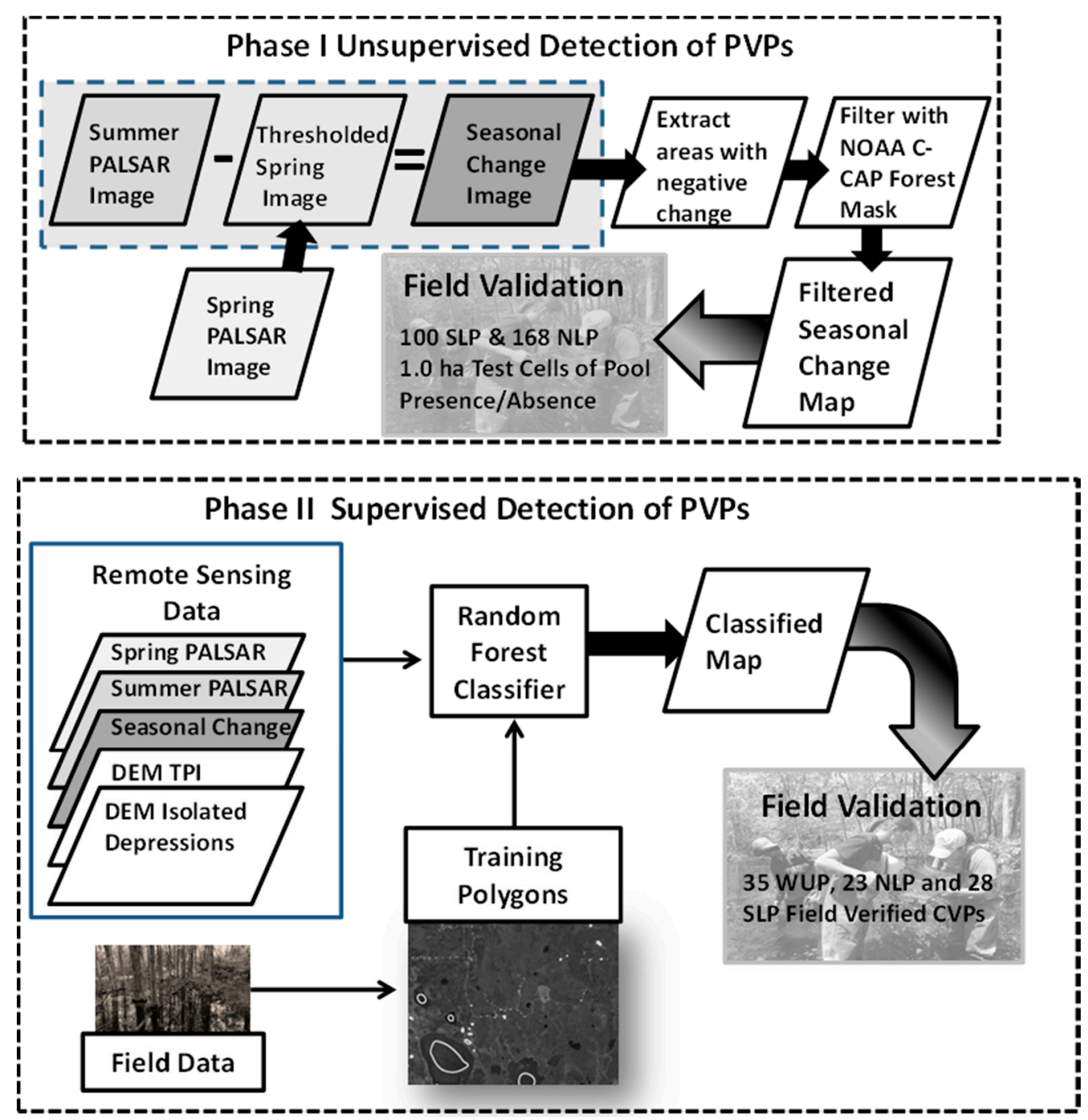

Figure 5. Schematic diagram showing the Phase I (top panel) unsupervised approach to detecting PVPs and the Phase II (bottom panel) supervised Random Forests approach, including the datasets used for validation. The spring, summer and seasonal change PALSAR images are used in both approaches. WUP = western Upper Peninsula; NLP = northeastern Lower Peninsula; SLP = southeastern Lower Peninsula; PVPs = Potential Vernal Pools; CVPs = Confirmed Vernal Pools; -CAP = Coastal Change Analysis Program. 
In Phase II of the project, the machine learning classifier, Random Forests [39], was evaluated for mapping PVPs with the PALSAR and DEM-derivative datasets using field data for training (supervised classification, Figure 5). Random Forests (RF) is an ensemble classifier consisting of multiple decision trees generated from a random subset of training data sites and bands from a stack of all data. Once the forest of decision trees is created, an individual pixel's classification is determined by which class receives the most "votes" across all decision trees. RF has been demonstrated as suitable for regional wetland mapping [40-42].

For phase II (Figure 5), field data on specific CVP locations (not test cells) were used to create polygons to be used as training and validation data. The SAR and LiDAR images used in this study did not cover the entire areas that were field surveyed, therefore a subset were used for training and validation; 28 SLP, 23 NLP and 35 WUP CVPs fell within the imaged areas. For all other non-vernal pool (NVP) land cover types, polygons (121 SLP, 180 NLP, 161 WUP) were delineated by trained aerial photograph interpreters and included in the training and validation data. All polygons combined (CVP and NVP) represented $2.25 \mathrm{~km}^{2}$ of the SLP (total image area $554 \mathrm{~km}^{2}$ ) and $9.65 \mathrm{~km}^{2}$ of the NLP (total image area $1363 \mathrm{~km}^{2}$ ). The image area is based on an intersection of the remote sensing footprints and study area. An 80/20 split was made between training (80\%) and validation (20\%) data.

The SLP sites served as the location of PALSAR algorithm development and the methods were then applied to the NLP and WUP study areas. The RF classifier was also applied to the Radarsat-2 spring, summer, seasonal change and DEM data for the SLP, and WUP sites, while RF was applied to LiDAR and DEM data only for the SLP site.

\subsection{Accuracy Assessments}

\subsubsection{PALSAR Blind Potential Vernal Pool Mapping}

An accuracy assessment was performed by comparing PVP unsupervised mapping results to field sampling results of the 1 ha test cells surveyed for presence/absence of water beneath a forest canopy in 2012. Producer's and User's accuracies were calculated for each of the maps. User's accuracy is a measure of how accurately a classification performed in the field (errors of commission = $100-$ user's accuracy) while producer's accuracy is a measure of how accurately the analyst classified the image data (errors of omission $=100-$ producer's accuracy) [43].

The stratified random field sampling approach allowed for an assessment of the true positives (accuracy rate for mapping PVPs), true negatives (accuracy for mapping areas without vernal pools), as well as error rates associated with commission: false negatives (i.e., pools observed in the field but not mapped from remote sensing) and false positives (i.e., pools mapped from remote sensing that were not vernal pools).

\subsubsection{Supervised Classification of Vernal Pools}

For Phase II supervised classification, the maps were assessed for accuracy using the CVPs and traditional remote sensing producer's and user's accuracy assessments on a per pixel basis. There were a total of 23 CVPs in the NLP, 28 CVPs in the SLP study area and 35 CVPs in the WUP study areas that were surveyed and used for training and validation of the SAR imagery (L- and C-band).

\section{Results}

\subsection{SAR Blind Seasonal Change Map Results}

A comparison of a subset of the PALSAR Unsupervised PVP results from the SLP to the field sampled test cells for vernal pools (independent of remote sensing) is shown in Figure 6. The green polygons (Figure 6) are PALSAR-derived PVPs while the blue cells show 2 acre areas that were sampled in the field and were positive for standing water within or touching the cell, and the red cells show areas that were negative for standing water in the field. This example shows PVPs identified by 
PALSAR seasonal change detection for 5 of the 7 blue (positive standing water) cells and no false alarms in the three red cells. A full statistical analysis of the unsupervised PALSAR seasonal change products for the entire SLP and NLP study areas based on the random field sampling strategy provided a rigorous statistical analysis.

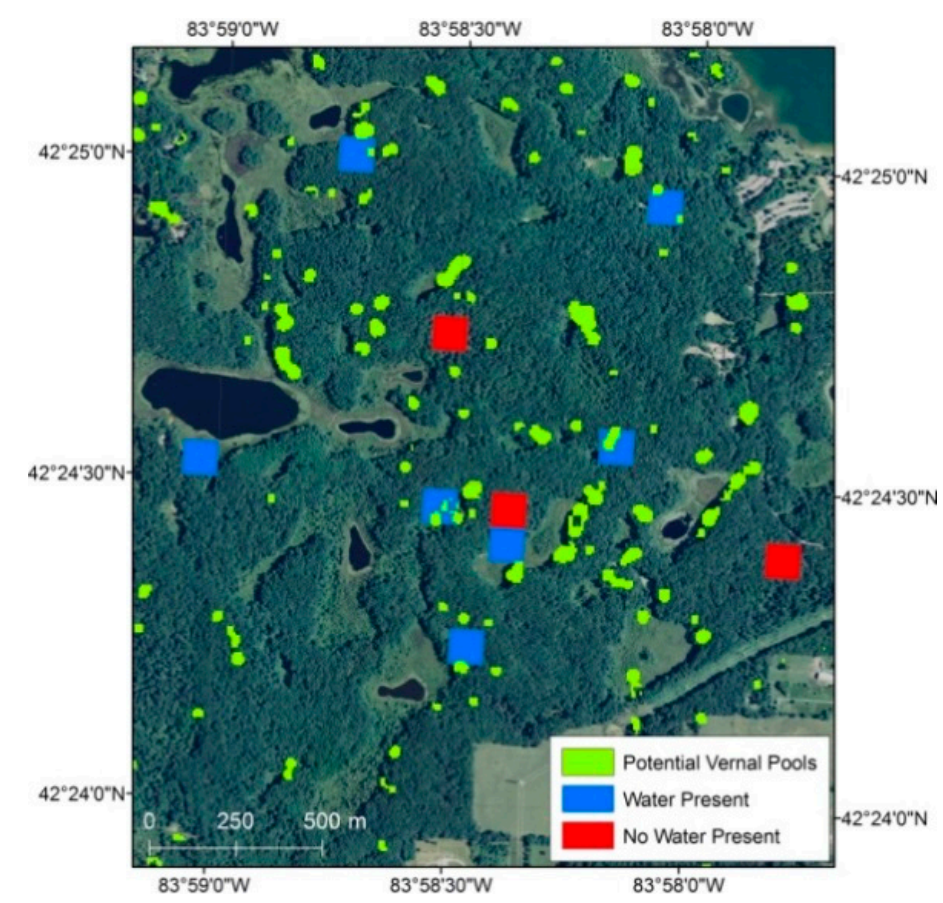

Figure 6. Green polygons are PALSAR-derived potential vernal pools in the Pinckney Recreation Area of the Southeastern Lower Peninsula study area. Red Cells are 2 acre field checked areas without water presence and blue Cells are those with water presence. Cells were chosen for field sampling independent of remote sensing.

A total of 268 test cells that were sampled in the SLP and NLP study areas (i.e., 100 test cells in the SLP, 168 test cells in the NLP) were used in the accuracy assessment of unsupervised SAR seasonal change for detecting PVPs. These results indicate that unsupervised PALSAR seasonal change has an overall detection accuracy of $62 \%$ in the SLP and $48 \%$ in the NLP (Table 2). The accuracy rate for unsupervised PALSAR seasonal change correctly identifying test cells with vernal pools in the field (i.e., true positives) was fairly low at 34\% overall across the SLP and NLP study areas. However, the accuracy rate for correctly identifying test cells that did not contain vernal pools in the field (i.e., true negatives) was much higher at $81 \%$ overall across the two study areas. The false positive errors were $51 \%$ in the SLP and 77\% in the NLP. There are two types of false positives, the ones that are not a waterbody and the ones that are a waterbody but not a vernal pool. Of the 33 test cells in the SLP that were false positives, 21 cells contained other wetlands/waterbodies that were not vernal pools, and 12 test cells contained no water and were dry. For the NLP, there were 72 test cells that were false positives and only 9 of these contained other wetlands/waterbodies that were not vernal pools. The other 62 test cells contained no water and were dry, and 1 test cell was inconclusive (sampled in the fall only).

The combined commission error rate for identifying and mapping vernal pools using unsupervised (blind) PALSAR seasonal change data was 66\% across the SLP and NLP study areas (Table 2). The overall false negative error rate (Table 2) for identifying and mapping non-vernal pools (NVP) was 19\% across the two study areas. False negatives error ranged from only $14 \%$ in the SLP study area to $22 \%$ in the NLP study area (Table 2). 
Table 2. Accuracy tables for the seasonal change unsupervised PALSAR PVP maps for southeastern Lower Peninsula (SLP, top) and northeastern Lower Peninsula (NLP, bottom). Categories are Potential Vernal Pool (PVP) and Non-Vernal Pool (NVP). Numbers represent field sampled test cells.

\begin{tabular}{|c|c|c|c|c|c|c|c|}
\hline \multirow{6}{*}{$\begin{array}{l}\text { Random } \\
\text { Stratified Field } \\
\text { Sampling }\end{array}$} & & \multicolumn{6}{|c|}{ Unsupervised PALSAR PVP Map-SLP } \\
\hline & & PVP & NVP & Sum & \multicolumn{2}{|r|}{ Omission Error } & $\begin{array}{l}\text { Producer } \\
\text { Accuracy }\end{array}$ \\
\hline & PVP & 32 & 5 & 37 & \multicolumn{2}{|r|}{$14 \%$} & $86 \%$ \\
\hline & NVP & \multirow{2}{*}{$\begin{array}{l}33 \\
65\end{array}$} & 30 & 63 & \multicolumn{2}{|r|}{$53 \%$} & $47 \%$ \\
\hline & Sum & & 35 & 100 & & \\
\hline & $\begin{array}{l}\text { Commission Error } \\
\text { User Accuracy }\end{array}$ & $\begin{array}{l}\text { False positives } 51 \% \\
\text { True positives } 49 \%\end{array}$ & \multicolumn{2}{|l|}{$\begin{array}{l}\text { False negatives } 14 \% \\
\text { True negatives } 86 \%\end{array}$} & \multicolumn{3}{|c|}{ Overall Accuracy 62\% } \\
\hline \multirow{7}{*}{$\begin{array}{l}\text { Random } \\
\text { Stratified Field } \\
\text { Sampling }\end{array}$} & & \multicolumn{6}{|c|}{ Unsupervised PALSAR PVP Map-NLP } \\
\hline & & PVP & \multicolumn{2}{|l|}{ NVP } & Sum & $\begin{array}{l}\text { Omission } \\
\text { Error }\end{array}$ & $\begin{array}{l}\text { Producer } \\
\text { Accuracy }\end{array}$ \\
\hline & PVP & 22 & \multicolumn{2}{|l|}{16} & 38 & $42 \%$ & $58 \%$ \\
\hline & NVP & 72 & \multicolumn{2}{|l|}{58} & 130 & \multirow[t]{2}{*}{$55 \%$} & \multirow{2}{*}{$45 \%$} \\
\hline & Sum & 94 & \multicolumn{2}{|l|}{74} & 168 & & \\
\hline & Commission Error & \multirow{2}{*}{$\begin{array}{l}\text { False positives } 77 \% \\
\text { True positives } 23 \%\end{array}$} & \multirow{2}{*}{\multicolumn{2}{|c|}{$\begin{array}{l}\text { False negatives } 22 \% \\
\text { True negatives } 78 \%\end{array}$}} & & \multirow{2}{*}{\multicolumn{2}{|c|}{ Overall Accuracy 48\% }} \\
\hline & User Accuracy & & & & & & \\
\hline
\end{tabular}

\subsection{Supervised Classifications of SAR, LiDAR, and DEM Datasets}

The spring and summer PALSAR backscatter images and Seasonal Change images, or LiDAR intensity data and USGS 10 m DEM TPI and Isolated Depressions products were used in Random Forests supervised classifications. Examples of these layers are shown in Figure 7 with an aerial image for reference and CVPs are shown as yellow dots. Review of these layers demonstrates that while any one product alone would not likely produce a robust PVP map, the fusion of data sources should allow for an improved map. These layers are of the same area shown in map outputs of Figure 8.
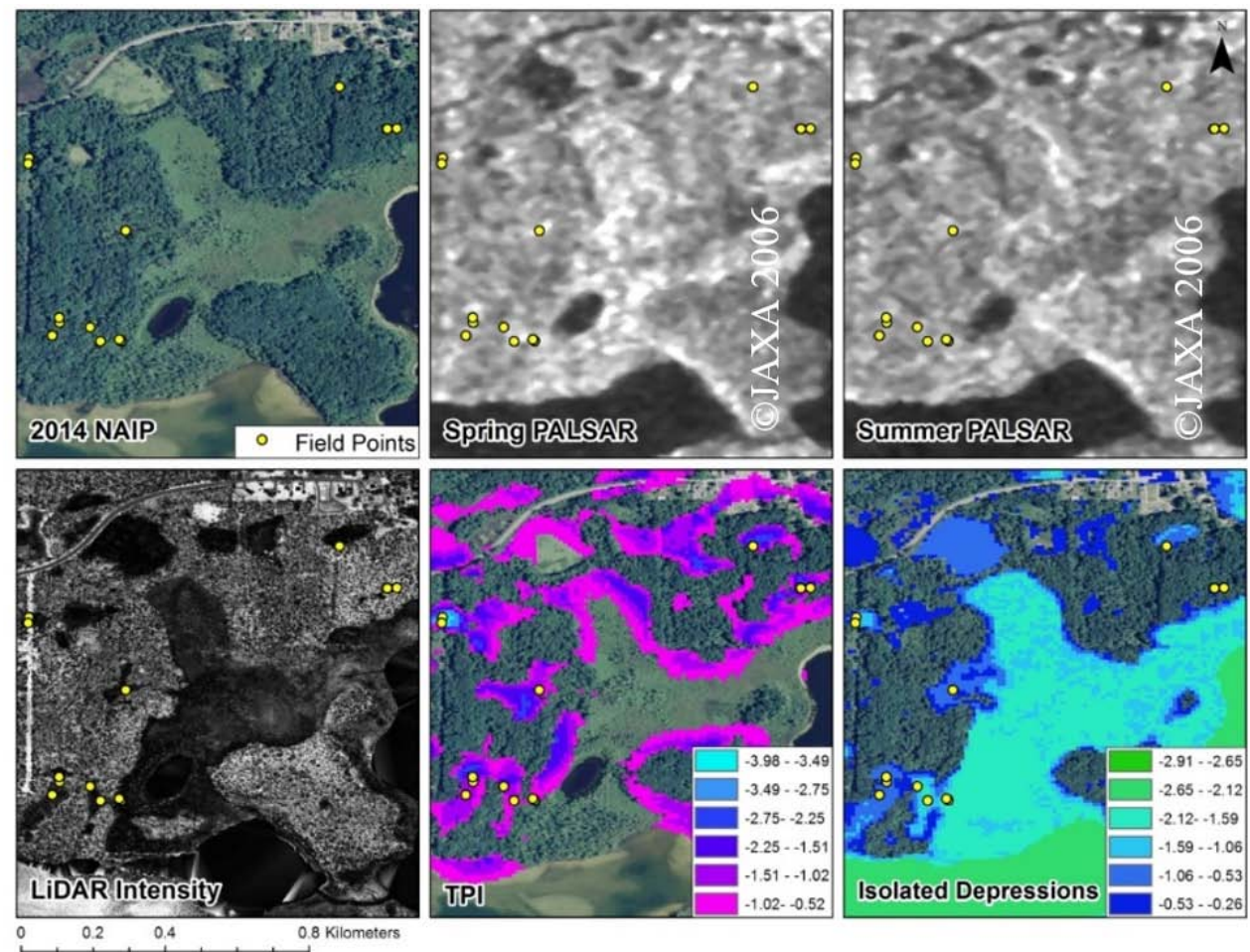

Figure 7. Examples of input data layers to Random Forests Classifier including Spring and Summer PALSAR L-HH backscatter, LiDAR intensity, USGS 10 m DEM Topographic Position Index (TPI) and Isolated Depressions products, with 2014 NAIP aerial photography for reference at Pinckney Recreation Area of southeastern Lower Peninsula (SLP) study area. Not shown is the Spring-Summer PALSAR change image. Yellow points show field verified vernal pool locations. 


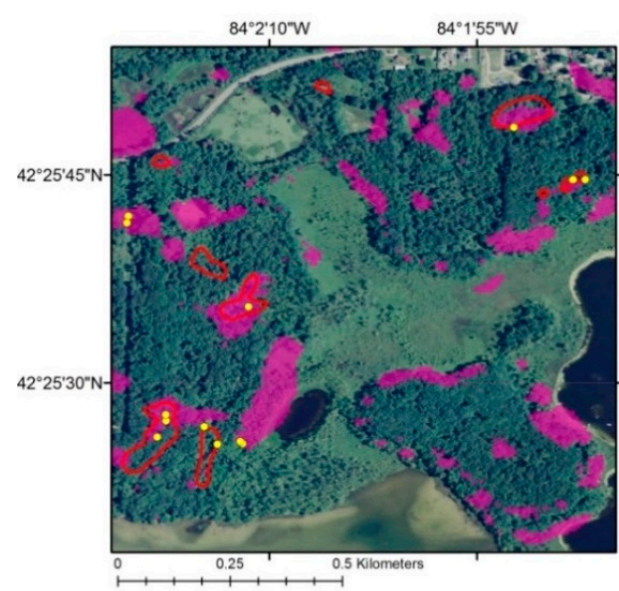

(a)

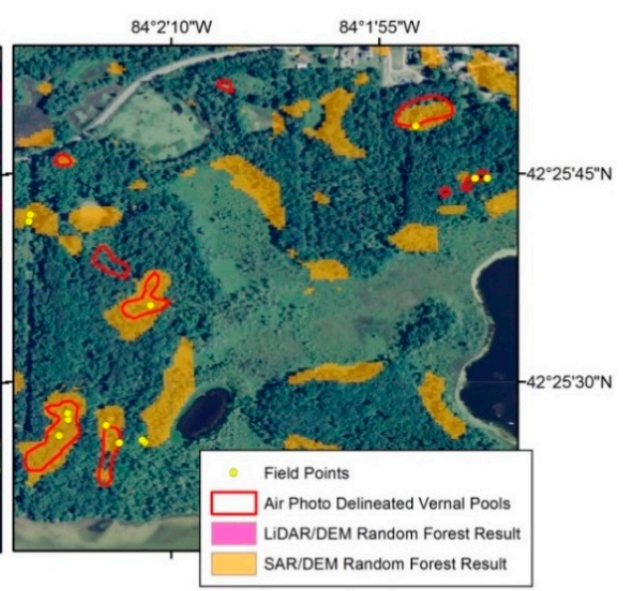

(b)

Figure 8. Comparison of the LiDAR and DEM potential vernal pool map ((a) pink polygons, Table 3) to SAR and DEM-generated potential vernal pool map ((b) orange polygons, Table 4). Red outlines show potential pools from air photos, and green dots are field verified locations of vernal pools. Numbers in tables represent pixels. These images are a subset of the larger area mapped.

Table 3. LiDAR Intensity and USGS DEM derivatives (TPI and isolated depressions) southeastern Lower Peninsula (SLP) Accuracy Assessment for potential vernal pools (PVPs) based on the Random Forests Classifier. Values represent number of pixels in each class. CE-Commission Error; UA-User's Accuracy; OE-Omission Error; and PA-Producer's Accuracy.

\begin{tabular}{|c|c|c|c|c|c|c|}
\hline \multirow{7}{*}{$\begin{array}{l}\text { Supervised } \\
\text { Class }\end{array}$} & \multicolumn{6}{|c|}{ Field Truthed Values } \\
\hline & & Other & PVP & Sum & CE & UA \\
\hline & Other & 198 & 120 & 318 & $38 \%$ & $62 \%$ \\
\hline & PVP & 12 & 75 & 87 & $14 \%$ & $86 \%$ \\
\hline & Sum & 210 & 195 & 405 & & \\
\hline & $\mathrm{OE}$ & $6 \%$ & $62 \%$ & & \multirow{2}{*}{\multicolumn{2}{|c|}{ Total Accuracy $=67 \%$}} \\
\hline & PA & $94 \%$ & $39 \%$ & & & \\
\hline
\end{tabular}

Table 4. PALSAR and USGS DEM derivatives (TPI and isolated depressions) southeastern Lower Peninsula (SLP) Accuracy Assessment for potential vernal pools (PVPs) based on the Random Forests Classifier. Values represent number of pixels in each class. CE-Commission Error; UA-User's Accuracy; OE-Omission Error; and PA-Producer's Accuracy.

\begin{tabular}{ccccccc}
\hline & \multicolumn{5}{c}{ Field Truthed Values } \\
\cline { 2 - 7 } Supervised & Other & PVP & Sum & CE & UA \\
\cline { 2 - 7 } Class & Other & 202 & 19 & 221 & $9 \%$ & $91 \%$ \\
& PVP & 11 & 182 & 193 & $6 \%$ & $94 \%$ \\
& Sum & 213 & 201 & 414 & & \\
& OE & $5 \%$ & $10 \%$ & & Total Accuracy $=93 \%$ \\
& PA & $94 \%$ & $39 \%$ & & \\
\hline
\end{tabular}

3.2.1. Comparison of Classification of Vernal Pools with PALSAR and $10 \mathrm{~m}$ DEM vs. LiDAR and $10 \mathrm{~m}$ DEM Data

The classification of LiDAR intensity and DEM derivative products (Figure 8a and Table 3) had $39 \%$ Producer's accuracy (62\% omission error) and $86 \%$ User's accuracy (14\% commission error), while the PALSAR and DEM classification (Figure 8b and Table 4 ) had 91\% Producer's accuracy (9\% omission error) and 94\% User's accuracy (6\% commission error). Although many of the areas are similar between the 2 products, notice the missed areas in the southwest corner of the LiDAR-DEM product (Figure 8a), which are captured in the SAR-DEM product (Figure 8b). The red outlines show 
PVPs mapped with aerial photograph interpretation and CVPs as yellow points [22]. Note how in many cases the red polygons are smaller than the area mapped by PALSAR in the right image of Figure 8 . This could be due to year to year variability in extent of inundation, since the SAR was collected in a different year than the aerial imagery or it could be overestimation by SAR. A few of the aerial photography interpreted PVPs are not captured with the PALSAR or the LiDAR.

\subsubsection{Application of SAR \& 10 m DEM Methodology to NLP Study Site}

Since the approach of using SAR and the derived $10 \mathrm{~m}$ DEM products had high accuracy for the SLP study region, the methods were applied to the NLP study area to determine robustness and transferability of the approach to another study site with different vegetation, topography and climate. The results are shown in Figure 9, with the blue polygons showing PVPs and the accuracy assessment in Table 5. CVPs are shown as green dots (Figure 9). Note that not all pools identified by the PALSAR-DEM methodology have been field visited.

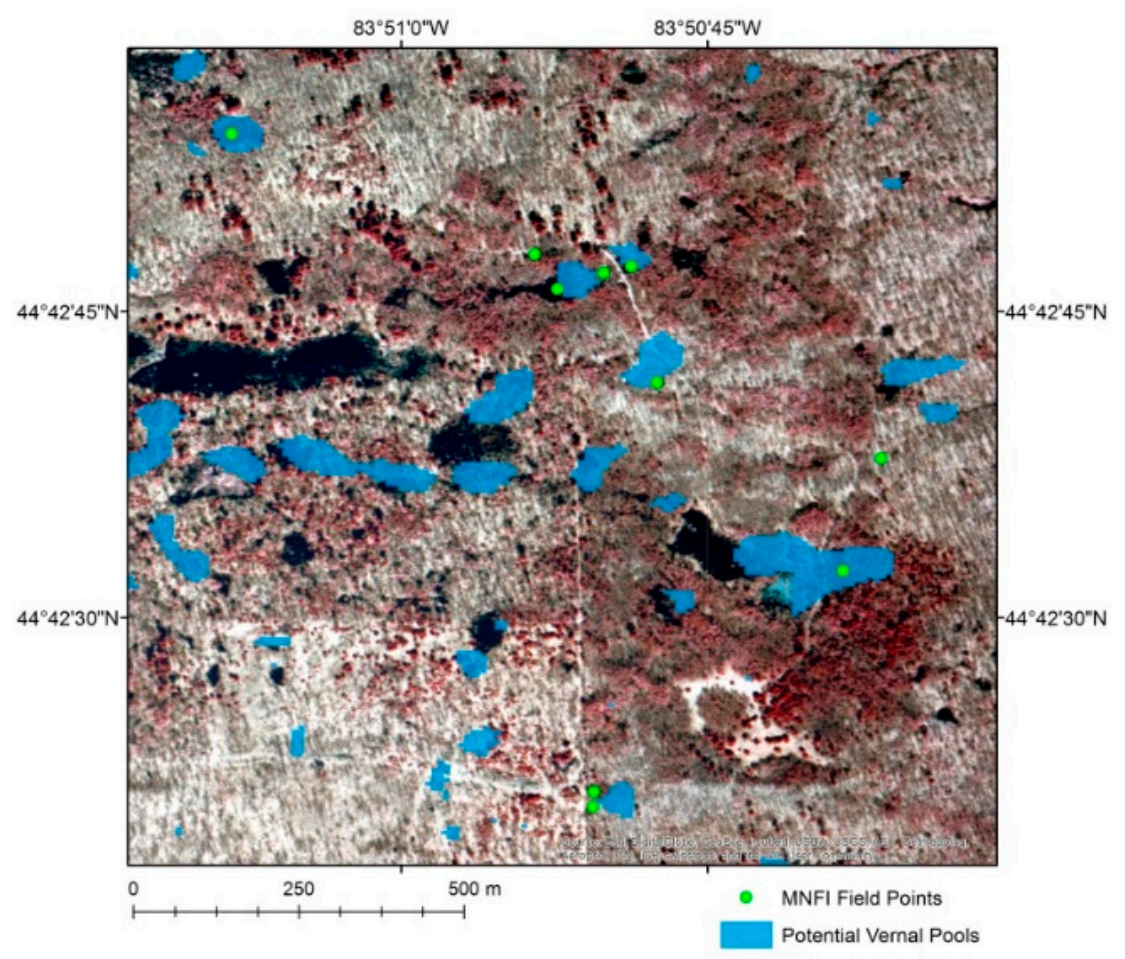

Figure 9. PALSAR potential vernal pool (PVP) map of northeastern Lower Peninsula (NLP) study area with leaf-on color infrared background image from April 1998. Accuracy assessment is next to the image with numbers representing number of pixels correctly or incorrectly identified based on validation training polygons.

Table 5. Northeastern Lower Peninsula (NLP) Accuracy Assessment for potential vernal pools (PVPs) based on the Random Forests Classifier with PALSAR and USGS DEM derivatives (Topographic Position Index and isolated depressions). Values represent number of pixels in each class. CE-Commission Error; UA-User's Accuracy; OE-Omission Error; and PA-Producer's Accuracy.

\begin{tabular}{ccccccc}
\hline & \multicolumn{5}{c}{ Field Truthed Values } \\
\cline { 2 - 7 } Supervised & Other & PVP & Sum & CE & UA \\
\cline { 2 - 7 } Class & Other & 216 & 35 & 251 & $14 \%$ & $86 \%$ \\
& PVP & 3 & 172 & 175 & $2 \%$ & $98 \%$ \\
& Sum & 219 & 207 & 426 & & \\
& OE & $1 \%$ & $17 \%$ & & Total Accuracy $=91 \%$ \\
& PA & $94 \%$ & $39 \%$ & & & \\
\hline
\end{tabular}




\subsubsection{Application of SAR \& $10 \mathrm{~m}$ DEM Methodology to WUP Study Area}

While the PALSAR and $10 \mathrm{~m}$ DEM method proved to be successful in the SLP and NLP study areas, we were unable to create a PVP map for the WUP study area due to lack of suitable data. The timing of the PALSAR data collection is critical for detection of the inundation condition versus the "dry" condition. The available PALSAR data for the WUP study area were less than ideal. Due to its more northerly location, spring onset is typically later than the early April image date that was available from PALSAR FBS. Timely SAR data collected after snowmelt and during vernal pool inundation is critical to the mapping process. The approach developed for the NLP and SLP sites should prove useful for PVP detection where suitable data are available throughout the Great Lakes region.

\subsubsection{C-Band Preliminary Evaluation}

For the Pinckney Recreation Area of the SLP study area, spring C-band radar data collected in April 2014 were ideal for capturing the inundation condition before full leaf flush (Figure 10). Of the six CVPs within the example area shown in Figure 10, four were partially detected with Radarsat-2. One of the undetected CVPs was not covered by a tree canopy but had a large opening in the surrounding forest. For such an open area, the double bounce (strong SAR return) characteristic of inundated trees would not occur. In comparison to the PALSAR PVP map of this similar area (Figure 8) and the CVP boundaries (Figure 10), the C-band sensor appears to only pick up partial pools (yellow polygons). However, the image collection years were different between the PALSAR and Radarsat-2, so if one year was drier or imagery was collected later in the season this possibly could account for these differences. However, it is likely that the shorter wavelength of C-band is simply not picking up the entire pool due to penetration limitations.

(a)

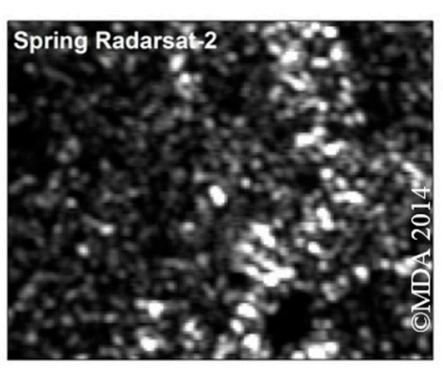

(b)
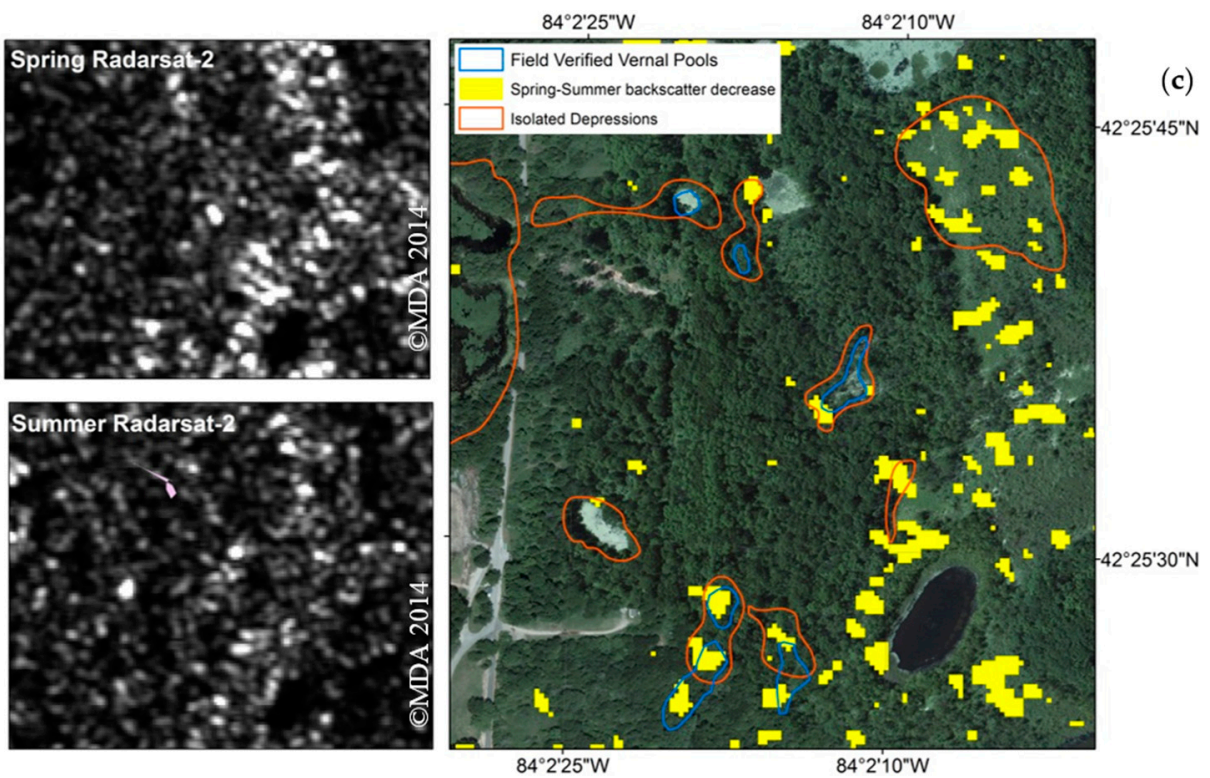

Figure 10. Areas exhibiting high backscatter appear bright in the Radarsat-2 image from 25 April (a) while appearing darker in the image collected on 29 July (b); Field verified vernal pools are outlined in blue; (c) shows the Radarsat-2 Seasonal Change product (yellow) overlaid with air photo mapped PVPs (blue) and isolated depressions outlined in red.

The Radarsat-2 images for the WUP study area did not exhibit enough variability between the spring and summer data collected for field sampled vernal pools to be detected. The vernal pools of the WUP were quite small and the spring imagery was collected on 31 May 2014, which was past leaf flush. 


\section{Discussion}

It has long been known that inundation beneath a forest canopy could be detected with $\mathrm{L}$ band HH-polarization SAR data [44] and in some cases with C-HH imagery $[26,45,46]$ through enhanced backscatter returns. However, detection of seasonal inundation in small isolated wetlands, such as vernal pools, which can sometimes be only $15 \mathrm{~m}$ across, was uncertain with an 8-10 m resolution SAR. Detection beneath a forest canopy requires not only careful timing of the seasonal imagery, but also high spatial resolution and $10 \mathrm{~m}$ resolution may be near the limit for a SAR for this application due to speckle.

The phase I study demonstrated the utility of L-band $\mathrm{HH}$ polarization $10 \mathrm{~m}$ resolution data for detection of cryptic vernal pools in two study areas (NLP and SLP) with overall accuracy of $48 \%$ and $62 \%$, respectively. The SAR PVP products were compared to stratified random field sampling cells of the study areas which allowed for a fairly robust accuracy assessment of errors in seasonal SAR PVP detection. However, due to the large size of the test cells in relation to the small size of vernal pools, our validation may be biased with inflated true positives. For example, the SAR seasonal change could map a PVP polygon in the 1.0 ha cell in a different location than the field verified vernal pool, but with the large test cell size it would be marked a true positive. At the same time, due to the ephemeral nature of vernal pools, the mismatch of year and season of imagery to year and season of field sampling could also be biasing our results; thus, the number of true negatives could be overestimated.

True positives were higher at the SLP study area (49\%) than the NLP study area (23\%). This may be due to the timing of the imagery at each site in relation to the hydroperiod status. It may also be due to differences in vegetation structure and physiography. Average water depths were similar between the SLP and NLP $(\sim 45 \mathrm{~cm})$ at the time of field sampling. However, timing of the satellite imagery was not necessarily at the peak water depth for each of the study areas. It is also interesting that more of the false positives of SLP (63\%) were water bodies that were not CVPs than for the NLP $(13 \%)$. The causes of these differences are in need of further investigation. However, one of the features that we have found to cause false positives is the existence of structures (homes, barns, etc.) beneath a tree canopy. Such man-made structures may cause some double bounce scattering in spring with wet soil conditions and lower return in summer when the soil is dry. The exact nature of the false positives needs further investigation with coincident SAR and field collection.

Due to the low false negative rates at both study areas (22\% and $14 \%)$, SAR was deemed suitable for narrowing down the search in detecting otherwise cryptic vernal pools. Even though this was higher than the false negative error for aerial photograph interpretation $(7 \%$; [23]), the cost-effectiveness of SAR makes it appropriate. When the location of vernal pools is largely unknown, some method to narrow down the areas to conduct further detection through field surveys or aerial photography is desirable since the latter two methods can be a formidable task. While the phase I analysis did not provide an assessment of discrete delineation of PVP boundaries, the phase II supervised classification did.

In phase II, supervised classification of the PALSAR data with derived DEM products ( $91 \%-93 \%$ overall accuracy) was implemented to improve the detection and mapping of vernal pool boundaries. Using multiple sources of imagery or ancillary information allows cross checks on the variables that define a vernal pool, thus improving map accuracy. The PALSAR RF classification that included $10 \mathrm{~m}$ DEM-derived isolated depressions and TPI products was demonstrated as superior to LiDAR intensity data with the same DEM products (34\% overall accuracy) for detection and mapping of vernal pools in this study. Although the spring LiDAR intensity image alone (Figure 6) appears to well delineate the vernal pools, it produces many false alarms, and when combined with the DEM product misses some CVPs (Figure 7). Combining the spring LiDAR intensity data with the PALSAR may be a viable option.

As more LiDAR data become available for the state of Michigan, pursuing LiDAR DEM data for vernal pool mapping in combination with L-band SAR would likely improve mapping capability even further. Wu et al. [24] described an accurate method of using LiDAR-derived DEMs with color orthoimagery and hydrography data to identify vernal pools in Massachusetts. Their approach to using the LiDAR-derived DEMs avoided the issues of surface complexity recognized for this study, 
and further exploration could improve the accuracy of vernal pool detection in Michigan where LiDAR data are available. Additionally, Faccio et al [25] presented another LiDAR-based method used to map vernal pools in Vermont and New Jersey. Their method takes advantage of LiDAR intensity data, as well as other ancillary datasets, to detect vernal pools with an Object Based Image Analysis (OBIA) approach.

Although L-band is theoretically and practically better suited to detection of inundation beneath a forested canopy, C-band data from Radarsat-2 were preliminarily evaluated in this study. Previous work has shown $5.7 \mathrm{~cm}$ C-band data from Radarsat-1 as useful for detection of inundation beneath a forest canopy in Roanoke riparian wetlands [45,47]. Although the spring and summer C-Band SAR data were useful for detection of seasonal differences in flooding in vernal pools in the SLP, they were not able to detect sufficient variability in backscatter to detect PVPs in the WUP study area. The resolution of the USGS DEM may be too coarse to detect isolated depressions in the WUP. At the time of the WUP spring Radarsat-2 image collection, there was standing water in the vernal pools, but the leaves had fully flushed, which may be limiting the ability of the C-band SAR wavelength to reach the ground. The pools in WUP were also much smaller than in Pinckney and the canopy cover was more coniferous. This then leads to questions about the dry (summer) C-band SAR collections, and if leaves limit the penetration capability, then the methodology of differencing of spring and summer data would be of question. Leaf flush had just begun when the Pinckney spring image was collected, which may explain why it was possible to detect vernal pools there with the Spring-Summer seasonal difference image. The fact that the pools detected are smaller than those field-verified and mapped from aerial photograph interpretation or PALSAR may be due to more closed canopy conditions in the summer. Further investigation into the forest structural differences between these vernal pool locations is needed before conclusions may be drawn, but early spring collections before leaf-flush appear to have potential for detection of PVPs with C-band data, however L-band is better suited.

The only SAR sensors available for mapping at L-band at the time of this article were ALOS PALSAR (2006-2011) and ALOS-2 PALSAR-2 (2013-present). The availability of PALSAR-2 is more limited in comparison to the predecessor satellite, ALOS PALSAR. While PALSAR was available for minimal to no cost through the Alaska Satellite Facility (AFS) for North America, PALSAR-2 is available only through JAXA [48] at high cost. Looking to the future, Argentina plans to launch an L-band satellite, SAOCOM, in 2017 and NASA is planning a mission with ISPRA called NISAR. This latter satellite has a mission plan that includes downloading and storing all data collected every 2 weeks. This will tremendously improve timely data collection of "wet" vs. "dry" vernal pool conditions over the past satellites that downlinked and saved only some of the data due to recorder and downlink station limitations. For those pools that were missed with the seasonal change approach because they were not wet in the particular spring imagery that was available or they were still wet on the image collection date that was used as the "dry" condition, having continuous data every 2 weeks will greatly improve detection capability, but also allow for determination of hydroperiod.

\section{Conclusions}

The research presented has demonstrated the utility of high resolution L-band SAR for detection of potential vernal pools through a seasonal change approach to detect the seasonal hydrological change (inundated to non-inundated) that defines a vernal pool. Using an unsupervised SAR seasonal change approach allows for the area of PVP locations to be reduced dramatically with low false negatives of vernal pools, but has high false positives and true negatives (Table 2). This may be a useful quick, cost-effective approach to narrow down a region to those areas of high likelihood of PVP locations to aid in directing follow up aerial photograph interpretation and field sampling to verify the vernal pool status. When a $10 \mathrm{~m} \mathrm{DEM}$ is available, integrating that ancillary dataset with L-band SAR in a supervised classification was shown to substantially reduce the commission and omission errors of PVPs. Additionally, if leaf-off LiDAR or high resolution optical imagery were also integrated 
into the classification scheme with the L-band SAR, it should improve map accuracy and vernal pool delineation even more.

The novel seasonal change SAR approach to detection and mapping of woodland vernal pools (PVPs) provides an alternative to expensive airborne sensor data collection and with new sensors planned for launch in the next 1-5 years is a viable approach for detection, mapping and monitoring of PVPs. Incorporating L-band SAR and a more robust LiDAR-based topographic analysis into a classification scheme is a promising potential next step for vernal pool mapping and detection in Michigan. L-band data have the added advantage of detection of inundation beneath evergreen canopies, conditions under which LiDAR and optical data have limited capability.

Due to the archival nature of much of the imagery (PALSAR and LiDAR) used in this study, a determination of actual vernal pool extent on the ground in comparison to the supervised PVP classified polygon results was not possible. This is generally true for the use of aerial photographs as well, which are often accessed from as many years as possible to detect PVPs. Although the pools change in hydroperiod and extent from year to year, and in some years may not be wet, remote sensing provides the most viable tool to detect location of PVPs across large regions. The maps of PVPs created from a single or multiple years of imagery provide a starting point upon which to build a database of PVP locations. These locations then need to be confirmed in the field, checking for draw down in the summer and species presence. Using the new L-band satellites (PALSAR-2, SAOCOM and NISAR) with coincident field data collected in the spring when the vernal pools are inundated will allow for determination of the capability and limitations of L-band SAR-DEM methods in delineating vernal pool boundaries.

Acknowledgments: The project was funded by a U.S. Environmental Protection Agency (U.S. EPA) Region 5 Wetland Program Development Grant through the Michigan Wetlands Protection Program in the Wetlands, Inland Lakes and Streams Unit of the Water Resources Division within the Michigan Department of Environmental Quality (MDEQ), Project \#10-WL-002. The statements, findings, conclusions, and recommendations provided in this publication are those of Michigan Tech Research Institute, the Michigan Natural Features Inventory and Michigan State University (MSU) and do not necessarily reflect the views of the DEQ and the U.S. EPA. Funding of the 2014 field data collection and Radarsat-2 image analysis was provided through Cooperative Agreement \#30181AJ195 with the US Fish and Wildlife Service and Verso, MDNR, Michigan Forests Products Council, and MNFI. Data from Radarsat-2 was provided by SOAR-grant \# 5131. We would like to acknowledge researchers who helped collect 2012-2014 field data including Peter Badra, Elizabeth Banda, Anthony Chavez, John Fody, Joann Jeplawy, Brian Klatt, Michael Monfils, Rebecca Norris, Michael Penskar, and Ashley Suiter. We also would like to acknowledge additional cooperators who provided technical assistance and guidance and administrative support for the project including Joshua Cohen, Amy Clark Eagle, Amy Derosier, Helen Enander, Chad Fizzell, Anne Garwood, Alicia Ihnken, Garret Johnson, Michael Kost, Jeffrey Lee, Amy Lounds, Chris May, David Mifsud, Suzanne Ridge, Edward Schools, Patricia Thompson, and Nancy Toben. In addition, we thank Eleanor Serocki for her assistance in formatting and editing and Maria Chavez for her assistance in creating the schematic diagram.

Author Contributions: Lee and Bourgeau-Chavez conceived and designed the experiments; Battaglia, Scarbrough and Endres performed the remote sensing processing, calibration and classifications; all co-authors analyzed the data; Laubach, Battaglia, Endres, Bourgeau-Chavez and Lee contributed to the field sampling; Bourgeau-Chavez, Lee, Laubach, Battaglia and Endres wrote the paper".

Conflicts of Interest: The authors declare no conflict of interest.

\section{Abbreviations}

The following abbreviations are used in this manuscript:

$\begin{array}{ll}\text { PVP } & \text { Potential Vernal Pool } \\ \text { CVP } & \text { Confirmed Vernal Pool } \\ \text { SAR } & \text { Synthetic Aperture Radar } \\ \text { SLP } & \text { Southeastern Lower Peninsula of Michigan } \\ \text { NLP } & \text { Northeastern Lower Peninsula of Michigan } \\ \text { WUP } & \text { Western Upper Peninsula of Michigan }\end{array}$




\section{References}

1. Zedler, P.H. Vernal pools and the concept of "isolated wetlands". Wetlands 2003, 23, 597-607. [CrossRef]

2. Brooks, R.T.; Doyle, K.L. Shrew species richness and abundance in relation to vernal pond habitat in southern New England. Northeast. Nat. 2001, 8, 137-148. [CrossRef]

3. Joyal, L.A.; McCollough, M.; Hunter, M.L. Landscape ecology approaches to wetland species conservation: A case study of two turtle species in southern Maine. Conserv. Biol. 2001, 15, 1755-1762. [CrossRef]

4. Roe, J.H.; Kingsbury, B.A.; Herbert, N.R. Wetland and upland use patterns in semi-aquatic snakes: Implications for wetland conservation. Wetlands 2003, 23, 1003-1014. [CrossRef]

5. Colburn, E.A. Vernal Pools: Natural History and Conservation; The McDonald and Woodward Publishing Company: Granville, OH, USA, 2004; p. 426.

6. Brooks, R.T.; Ford, W.M. Bat activity in a forest landscape of central Massachusetts. Northeast. Nat. 2005, 12, 447-462. [CrossRef]

7. Francl, K.E. Bat Activity in Woodland Vernal Pools; Service, U.F., Ed.; Ottawa National Forest and University of Notre Dame: Notre Dame, IN, USA, 2005.

8. Paton, P.W. A review of vertebrate community composition in seasonal forest pools of the northeastern United States. Wetl. Ecol. Manag. 2005, 13, 235-246. [CrossRef]

9. Hanowski, J.; Danz, N.; Lind, J. Response of breeding bird communities to forest harvest around seasonal ponds in northern forests, USA. For. Ecol. Manag. 2006, 229, 63-72. [CrossRef]

10. Scheffers, B.R.; Harris, J.B.C.; Haskell, D.G. Avifauna associated with ephemeral ponds on the Cumberland Plateau, Tennessee. J. Field Ornithol. 2006, 77, 178-183. [CrossRef]

11. Calhoun, A.J.; DeMaynadier, P.G. Science and Conservation of Vernal Pools in Northeastern North America: Ecology and Conservation of Seasonal Wetlands in Northeastern North America; CRC Press: Boca Raton, FL, USA, 2007.

12. Battle, J.M.; Golladay, S.W. Hydroperiod influence on breakdown of leaf litter in cypress-gum wetlands. Am. Midl. Nat. 2001, 146, 128-145. [CrossRef]

13. Leibowitz, S.G. Isolated wetlands and their functions: An ecological perspective. Wetlands 2003, 23, 517-531. [CrossRef]

14. Gibbons, J.W.; Winne, C.T.; Scott, D.E.; Willson, J.D.; Glaudas, X.; Andrews, K.M.; Todd, B.D.; Fedewa, L.A.; Wilkinson, L.; Tsaliagos, R.N.; et al. Remarkable amphibian biomass and abundance in an isolated wetland: Implications for wetland conservation. Conserv. Biol. 2006, 20, 1457-1465. [CrossRef] [PubMed]

15. Duffy, W.G.; Kahara, S.N. Wetland ecosystem services in California's Central Valley and implications for the Wetland Reserve Program. Ecol. Appl. 2011, 21, S18-S30. [CrossRef]

16. Stone, J.S. Vernal Pools in Massachusetts: Aerial Photographic Identification, Biological and Physiographic Characteristics, and State Certification Criteria. Master's Thesis, University of Massachusetts, Amherst, MA, USA, 1992.

17. Brooks, R.T.; Stone, J.; Lyons, P. An inventory of seasonal forest ponds on the Quabbin Reservoir watershed, Massachusetts. Northeast. Nat. 1998, 5, 219-230. [CrossRef]

18. Burne, M.R.; Lathrop, R.G. Remote and field identification of vernal pools. In Science and Conservation of Vernal Pools in Northeastern North America; Calhoun, A.J.K., Demaynadier, P.G., Eds.; CRC Press: Boca Raton, FL, USA, 2007; pp. 55-68.

19. Lathrop, R.G.; Montesano, P.; Tesauro, J.; Zarate, B. Statewide mapping and assessment of vernal pools: A New Jersey case study. J. Environ. Manag. 2005, 76, 230-238. [CrossRef] [PubMed]

20. Burne, M.R. Massachusetts aerial photo survey of potential vernal pools. In Natural Heritage and Endangered Species Program; Massachusetts Division of Fisheries and Wildlife: Westborough, MA, USA, 2001; p. 80.

21. Tiner, R.W. Use of high-altitude aerial photography for inventorying forested wetlands in the United States. For. Ecol. Manag. 1990, 33, 593-604. [CrossRef]

22. Calhoun, A.J.; Walls, T.E.; Stockwell, S.S.; McCollough, M. Evaluating vernal pools as a basis for conservation strategies: A Maine case study. Wetlands 2003, 23, 70-81. [CrossRef]

23. Lee, Y.; Badra, P.J.; Battaglia, M.; Bourgeau-Chavez, L.L.; Enander, H.D.; Hyde, D.A.; Klatt, B.J.; Laubach, Z.; Monfils, M.J.; Penskar, M.R.; et al. Developing an Approach for Identifying, Mapping, and Assessing Vernal Pools in Michigan; Michigan Natural Features Inventory: Lansing, MI, USA, 2014. 
24. Wu, Q.; Lane, C.; Liu, H. An effective method for detecting potential woodland vernal pools using high-resolution LiDAR data and aerial imagery. Remote Sens. 2014, 6, 11444-11467. [CrossRef]

25. Faccio, S.D.; MacFaden, S.W.; Lambert, J.D.; O’Neil-Dunne, J.; McFarland, K.P. The North Atlantic Vernal Pool Data Cooperative; North Atlantic Landscape Conservation Cooperative: Hadley, MA, USA, 2015.

26. Lang, M.W. Improved Detection of Forested Wetland Hydrology with LiDAR Intensity. Wetlands 2009, 29, 1166-1178. [CrossRef]

27. Albert, D. Regional Landscape Ecosystems of Michigan, Minnesota and Wisconsin: A Working Map and Classification. Available online: http:/ /www.treesearch.fs.fed.us/pubs/10242 (accessed on 3 June 2016).

28. Cohen, J. Natural Community Abstract for Mesic Northern Forest; Michigan Natural Features Inventory: Lansing, MI, USA, 2000.

29. Volunteer Training Manual: Michigan Vernal Pool Mapping and Monitoring Project. Available online: https:/ / www.stewardshipnetwork.org/resources/volunteer-training-manual-michigan-vernalpool-mapping-and-monitoring-project (accessed on 3 June 2016).

30. Quick Terrain Modeler, Applied Imagery: Chevy Chase. Available online: http://appliedimagery.com/ (accessed on 6 June 2016).

31. 3D Elevation Program (3DEP). Available online: http:/ / nationalmap.gov/3DEP/ (accessed on 6 June 2016).

32. Weiss, A. Topographic Position and Landforms Analysis; Poster Presentation, ESRI User Conference: San Diego, CA, USA, 2001; p. 200.

33. Ulander, L.M. Radiometric slope correction of synthetic-aperture radar images. IEEE Trans. Geosci. Remote Sens. 1996, 34, 1115-1122. [CrossRef]

34. ASF MapReady User Manual. Available online: https://www.google.com.hk/url?sa=t\&rct=j\&q=\&esrc= s\&source=web\&cd=2\&cad=rja\&uact=8\&ved=0ahUKEwio5fu5lIvNAhUGEpQKHVm_DiQQFgggMAE\&

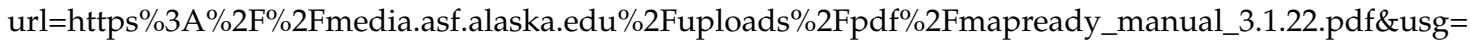
AFQjCNEuMPwjNGWVCoZ25NPUy5Ln2sY0kQ (accessed on 3 June 2016).

35. Shimada, M.; Rosenquvist, A.; Watanabe, M.; Tadono, T. The polarimetric and interferometric potential of ALOS PALSAR. In Proceedings of the 2nd International Workshop POLINSAR, Frascati, Italy, 17-21 January 2005.

36. PALSAR CALVAL Summary (JAXA-PI193). Available online: http://www.eorc.jaxa.jp/ALOS/en/conf/ Proc_PIsymp2007/contents/proceedings/SAR_Cal_Val/SCV13.pdf (accessed on 6 June 2016).

37. Cote, S.; Muir, S.; Srivastava, S.; Hawkins, R. SAR image quality and calibration operations for the RADARSAT satellites at the Canadian Space Agency. In Proceedings of the 2009 Radar International Conference "Surveillance for a Safer World" (Radar 2009), Bordeaux, France, 12-16 October 2009; pp. 1-6.

38. National Oceanic and Atmospheric Administration. 2010 Michigan Land Cover; National Oceanic and Atmospheric Administration: Charleston, SC, USA, 2010.

39. Breiman, L. Random forests. Mach. Learn. 2001, 45, 5-32. [CrossRef]

40. Bourgeau-Chavez, L.; Endres, S.; Battaglia, M.; Miller, M.E.; Banda, E.; Laubach, Z.; Higman, P.; Chow-Fraser, P.; Marcaccio, J. Development of a bi-national Great Lakes coastal wetland and land use map using three-season PALSAR and Landsat imagery. Remote Sens. 2015, 7, 8655-8682. [CrossRef]

41. Whitcomb, J.; Moghaddam, M.; McDonald, K.; Kellndorfer, J.; Podest, E. Mapping vegetated wetlands of Alaska using L-band radar satellite imagery. Can. J. Remote Sens. 2009, 35, 54-72. [CrossRef]

42. Corcoran, J.; Knight, J.; Brisco, B.; Kaya, S.; Cull, A.; Murnaghan, K. The integration of optical, topographic, and radar data for wetland mapping in northern Minnesota. Can. J. Remote Sens. 2012, 37, 564-582. [CrossRef]

43. Congalton, R.; Green, K. Assessing the Accuracy of Remotely Sensed Data: Principles and Applications; Lewis Publishers: Boca Raton, FL, USA, 1999.

44. Hess, L.L.; Melack, J.M.; Filoso, S.; Wang, Y. Delineation of inundated area and vegetation along the Amazon floodplain with the SIR-C synthetic aperture radar. IEEE Trans. Geosci. Remote Sens. 1995, 33, 896-904. [CrossRef]

45. Townsend, P. Relationships between forest structure and the detection of flood inundation in forested wetlands using C-band SAR. Int. J. Remote Sens. 2002, 23, 443-460. [CrossRef]

46. Bourgeau-Chavez, L.; Kasischke, E.S.; Brunzell, S.M.; Mudd, J.P.; Smith, K.B.; Frick, A.L. Analysis of space-borne SAR data for wetland mapping in Virginia riparian ecosystems. Int. J. Remote Sens. 2001, 22, 3665-3687. [CrossRef] 
47. Townsend, P.A. Mapping seasonal flooding in forested wetlands using multi-temporal Radarsat SAR. Photogramm. Eng. Remote Sens. 2001, 67, 857-864.

48. JAXA, ALOS-PALSAR Imagery Download, PLATFORM. Available online: https://satpf.jp/spf/?lang=en (accessed on 9 June 2016). article distributed under the terms and conditions of the Creative Commons Attribution (CC-BY) license (http:/ / creativecommons.org/licenses/by/4.0/). 